\title{
Postharvest biochemical characteristics and ultrastructure of Coprinus comatus
}

\author{
Yi Peng ${ }^{1,2}$, Tongling Li ${ }^{2}$, Huaming Jiang ${ }^{3}$, Yunfu Gu ${ }^{1}$, Qiang Chen ${ }^{1}$, Cairong Yang ${ }^{2,4}$, Wei liang Qi ${ }^{2}$, Song-qing \\ Liu Corresp., 2, 4 , Xiaoping Zhang ${ }^{\text {Corresp. } 1}$ \\ ${ }^{1}$ College of Resources, Sichuan Agricultural Uniersity, Chengdu, sichuan, China \\ ${ }^{2}$ College of Chemistry and Life sciences, Chengdu Normal University, chengdu, sichuan, china \\ 3 Sichuan Vocational and Technical College, Suining, sichuan, China \\ 4 Institute of Microbiology, Chengdu Normal University, Chengdu, sichuan, China \\ Corresponding Authors: Song-qing Liu, Xiaoping Zhang \\ Email address: biosq@126.com, zhangxiaopingphd@126.com
}

Background. Coprinus comatus is a novel cultivated edible fungus, hailed as a new preeminent breed of mushroom. However, $C$. comatus is difficult to keep fresh at room temperature after harvest due to high respiration, browning, self-dissolve and lack of physical protection.

Methods. In order to extend the shelf life of $C$. comatus and reduce its loss in storage, changes in quality, biochemical content, cell wall metabolism and ultrastructure of C. comatus (C.c77) under $4^{\circ} \mathrm{C}$ and $90 \%$ RH storage regimes were investigated in this study.

Results. The results showed that: (1) After 10 days of storage, mushrooms appeared acutely browning, cap opening and flowing black juice, rendering the mushrooms commercially unacceptable. (2) The activity of SOD, CAT, POD gradually increased, peaked at the day 10 , up to $31.62 \mathrm{U} \cdot \mathrm{g}^{-1} \bullet \mathrm{FW}, 16.51 \mathrm{U} \cdot \mathrm{g}^{-1}$ - FW, $0.33 \mathrm{U} \cdot \mathrm{g}^{-1} \mathrm{FW}$, respectively. High SOD, CAT, POD activity could be beneficial in protecting cells from ROS-induced injuries, alleviating lipid peroxidation and stabilizing membrane integrity. (3) The activities of chitinase, $\beta$-1,3-glucanase, Cx and PG were significantly increased. Higher degrees of cell wall degradation observed during storage might be due to those enzymes' high activities. (4) The fresh $C$. comatus had dense tissue and every single cell had the number of intracellular organelles which structure can be observed clearly. After 10d storage, the number of intracellular organelles was declined and the structure was fuzzy, the nucleus disappeared. After $20 \mathrm{~d}$ storage, $C$. comatus's organization was completely lost, many cells were stacked together and the cell wall was badly damaged. 
1 Postharvest biochemical characteristics and

2 ultrastructure of Coprinus comatus

3

4

5

6

7

8

9

Yi Peng ${ }^{1,2}$, Tongling $\mathrm{Li}^{2}$, Huaming Jang ${ }^{3}$, Yunfu $\mathrm{Gu}^{1}$, Qiang Chen ${ }^{1}$, Cairong Yang ${ }^{2,4}$, Wei liang $\mathrm{Qi}^{2}$, Song-qing Liu ${ }^{2,4^{*}}$, Xiaoping Zhang ${ }^{1 *}$

${ }^{1}$ College of Resources, Sichuan Agricultural Uniersity, Chengdu, Sichuan, China

${ }^{2}$ College of Chemistry and Life sciences, Chengdu Normal University, Chengdu, Sichuan, China

${ }^{3}$ Sichuan Vocational and Technical College, Suining, Sichuan, China

${ }^{4}$ Institute of Microbiology, Chengdu Normal University, Chengdu, Sichuan, China

Corresponding Author:

Xiaoping Zhang

No. 211 Huimin road, Wenjiang district, Chengdu, PR, 611130, China

Email address: zhangxiaopingphd@126.com

Song-qing Liu

No. 99, haike road, Wenjiang district, Chengdu, PR, 611130, China

Email address: biosq@126.com

\section{Abstract}

Background. Coprinus comatus is a novel cultivated edible fungus, hailed as a new preeminent breed of mushroom. However, C. comatus is difficult to keep fresh at room temperature after harvest due to high respiration, browning, self-dissolve and lack of physical protection.

Methods. In order to extend the shelf life of $C$. comatus and reduce its loss in storage, changes in quality, biochemical content, cell wall metabolism and ultrastructure of C. comatus (C.c77) under $4{ }^{\circ} \mathrm{C}$ and $90 \% \mathrm{RH}$ storage regimes were investigated in this study.

Results. The results showed that: (1) After 10 days of storage, mushrooms appeared acutely browning, cap opening and flowing black juice, rendering the mushrooms commercially unacceptable. (2) The activity of SOD, CAT, POD gradually increased, peaked at the day 10, up to $31.62 \mathrm{U} \cdot \mathrm{g}^{-1} \cdot \mathrm{FW} 、 16.51 \mathrm{U} \cdot \mathrm{g}^{-1} \cdot \mathrm{FW} 、 0.33 \mathrm{U} \cdot \mathrm{g}^{-1} \mathrm{FW}$, respectively. High SOD, CAT, POD activity could be beneficial in protecting cells from ROS-induced injuries, alleviating lipid peroxidation and stabilizing membrane integrity. (3) The activities of chitinase and $\beta-1,3-$ glucanase were significantly increased. Higher degrees of cell wall degradation observed during storage might be due to those enzymes' high activities. (4) The fresh $C$. comatus had dense tissue and every single cell had the number of intracellular organelles which structure can be observed clearly. After 10d storage, the number of intracellular organelles was declined and the structure was fuzzy, the nucleus disappeared. After $20 \mathrm{~d}$ storage, C. comatus's organization was completely lost, many cells were stacked together and the cell wall was badly damaged. 


\section{Introduction}

41 Coprinus comatus, also called as shaggy ink cap, is a novel cultivated edible fungus with

42

significantly commercial potential, hailed as a new preeminent breed of mushroom (Bo et al., 2010). Moreover, it is also a delicious and highly nutritious edible fungus, with numerous valuable medicinal compounds (Fan et al., 2006), including various bioactive functions, such as hypoglycemic, hypolipidemic, antibacterial effects (Bailey et al., 1985), immunomodulation, antitumor (Jiang et al., 2013) and antioxidant potential (Tsai \& Mau, 2009). However, $C$. comatus is difficult to keep fresh at room temperature after harvest due to high respiration, browning, self-dissolve and lack of physical protection (Rui \& Feng, 2006). The extremely active metabolic process and rapid deterioration of quality have seriously affected the commodity quality and shelf life of $C$. comatus, caused great losses to production and storage.

Under normal growing conditions, the production and clearance of intracellular free radicals and reactive oxygen species (ROS) are in a dynamic balance, however, this balance is destroyed with prolonged storage because the storage conditions are a sort of abiotic stress (Huang et al., 2007; Gill \& Tuteja, 2010). Followed by high generation capacity of ROS and low enzymatic antioxidant defense. Superoxide dismutase (SOD), peroxidase (POD), and catalase (CAT) were important parts of enzymatic antioxidant defense system, which can efficiently eliminate ROS (Duan et al., 2011). SOD is one of the key enzymes for scavenging free radicals in mushroom, which can transform superoxide anion radicals $\left(\mathrm{O}_{2}{ }^{--}\right)$to $\mathrm{H}_{2} \mathrm{O}_{2}$ and non-toxic molecular oxygen by catalyzing the disproportionation reaction. The CAT and POD could transform $\mathrm{H}_{2} \mathrm{O}_{2}$ into $\mathrm{H}_{2} \mathrm{O}$ and $\mathrm{O}_{2}$ through different actions, all of which are crucial for ROS detoxification (Prasad, Rosangkima \& Kharbangar, 2009).

During postharvest storage of edible fungi, changes in cell wall structure and composition directly contribute to cell separation, resulting in loose organizational structure and decreased hardness of fruiting body, finally, decreased storability of edible fungi (Zivanovic, Buescher \& Kim, 2003; Qi et al., 2015). Studies have addressed that the content of chitin decreased during postharvest storage due to the effect of chitinase by hydrolyzing the $\beta$-1, 4-glycoside bond in chitin and producing n-acetylglucosamine oligomer or monomer (Buitimea et al., 2013; Jiang et al., 2010). Lim \& Choi (2009) revealed that the Agaricus bisporus could rapidly produce black juice at $25^{\circ} \mathrm{C}$ for $15 \mathrm{~h}$ after harvest and confirmed that the amount of chitinase synthesis in the autolysis process was significantly higher than that of unpicked mushrooms. Xue (2012) studied the effect of postharvest calcium treatment on cell stability of Lentinula edodes and found that the stability of cell wall was correlated with $\beta$-1, 3-glucan and $\beta$-1, 3-glucanase, by inhibiting the activity of $\beta$-1, 3-glucanase, the aging of $L$. edodes could be delayed. Liu et al. (2015) suggests that $\beta$-1,3-glucanases plays a major role in the autolysis of Coprinopsis fruiting bodies. However, the accurate role of these enzymes in altering the cell wall of $C$. comatus after harvest were little known.

The degradation of cell wall substances and membrane lipid peroxidation led to changes in the ultrastructure of cells. Ultrastructure is also called submicroscopic structure. Electron microscope can well show the changes of tissue structure, cell structure, organelle function and

Peer) reviewing PDF | (2019:10:41863:2:0:NEW 26 Dec 2019) 
80

81

82

83

84

85

86

87 88

89

90

91

92

93

94

95

96

97

98

99

100

101

102

103

104

105

106

107

108

109

110

111

112

113

114

115

116

117

118

119

differentiation (Hu et al., 2015). By observing the ultrastructure of C. comatus, we can better understand the degradation mechanism of $C$. comatus after harvest. However, there was no report on the ultrastructure of C. comatus.

Therefore, it is necessary to conduct in-depth and systematic research on the physiological and biochemical changes of C. comatus after harvesting and try to find influencing factors and possible degradation mechanism of texture deterioration. The objective of this work was to investigate sensory characteristics, chemical properties, functional components, cell wall metabolic enzymes activity and ultrastructure of $C$. comatus during postharvest storage.

\section{Materials \& Methods}

\section{Materials}

C. comatus used in this study were harvested from an edible fungus planting base of Chengdu normal university in Sichuan, China (no. C.c77). C. comatus were transported to the laboratory in one hour after picking. Then, they $(60 \pm 5 \mathrm{~g})$ were screened for uniform size and maturity and absence of mechanical damage, packaged in low density polyethylene sealing bags $(0.04 \mathrm{~mm}$ thickness, size $18 \mathrm{~cm} \times 20 \mathrm{~cm}$ ). After that, samples were stored at $4{ }^{\circ} \mathrm{C}$ and $90 \%$ relative humidity (RH) for $20 \mathrm{~d}$. Subsequently every 5 days, three replicates were randomly selected and analyzed for each biochemical characteristic.

\section{Browning analysis}

We used a NR110 (Shenzhen 3nh technology co. LTD) type color difference meter (L, a, b) to determine the chromatism of $C$. comatus, and evaluated $\Delta E, \Delta E=$ $\left[(L-97)^{2}+(a-(-2))^{2}+b^{2}\right]^{1 / 2}$. L represents luminosity, which corresponds to brightness, a represents the range from magenta to green, $\mathrm{b}$ represents the range from yellow to blue. $\Delta E$ represents the overall color difference compared with the ideal or target color of the mushroom ( $\mathrm{L}=97, \mathrm{a}=-2, \mathrm{~b}=0$ ). The larger the $\mathrm{L}$, the smaller the $\Delta E$, indicating that the color of $C$. comatus is white and the degree of browning is lower.

\section{Weight loss analysis}

According to the method of Jiang, Feng \& Li (2012). It was expressed as the percentage of loss of weight with respect to the initial weight.

\section{Analysis of membrane permeability}

According to the method of Liu et al. (2010). Randomly selected 3-4 C. comatus, used a 5mm diameter puncher to punch holes in different parts, mixed and sampled $2 \mathrm{~g}$ in $50 \mathrm{ml}$ beaker, washed with no ion water several times, then add $30 \mathrm{~mL}$ without ionized water to soak $1 \mathrm{~h}$, conductivity of the surrounding solution was determined with a conductivity meter. The tissue was then boiled for 10min and the total conductivity was recorded. Electrolyte leakage was expressed as a percentage of total electrolytes in the tissue.

\section{Analysis of chemical properties}

Soluble protein was determined according to the method of Bradford (1976) using bovine serum albumin as standard. Malondialdehyde (MDA) content was determined according to the method of Jayakumar (Jayakumar, Ramesh \& Geraldine, 2006). $2 \mathrm{~g}$ of the fruit body of C. comatus was 
120 ground in $5 \mathrm{~mL} 5 \% \mathrm{TCA}$ using a mortar and pestle, and quickly cooled in an ice bath and

121

122

123

124

125

126

127

128

129

130

131

132

133

134

135

136

137

138

139

140

141

142

143

144

145

146

147

148

149

150

151

152

153

154

155

156

157

158

159

centrifuged at $8,000 \mathrm{r} / \mathrm{min}$ for $10 \mathrm{~min}$. Then $2 \mathrm{~mL}$ supernatant was ground in $2 \mathrm{~mL} 0.67 \% \mathrm{TBA}$, after heating at $100^{\circ} \mathrm{C}$ for $30 \mathrm{~min}$, the mixture was centrifuged again. The absorbance of the supernatant was read at $450 \mathrm{~nm}, 532 \mathrm{~nm}$ and $600 \mathrm{~nm}$ respectively. Concentration of MDA: $\mathrm{C}(\mu \mathrm{mol} / \mathrm{L})=6.45(\mathrm{~A} 532-\mathrm{A} 600)-0.56 \mathrm{~A} 450$.

$\mathrm{O}_{2}{ }^{-{ }^{-}}$was determined according to the methods of Jiang et al. (2010). Weighed $2 \mathrm{~g}$ of the mushroom, grinded with $6 \mathrm{~mL}$ of $65 \mathrm{mmol} / \mathrm{L}(\mathrm{pH} 7.8) \mathrm{PBS}$, centrifuged the filtrate at $7000 \mathrm{r} / \mathrm{min}$ for $5 \mathrm{~min}$ at $4{ }^{\circ} \mathrm{C}$, and took the supernatant. Determination of $\mathrm{O}_{2}{ }^{\cdot-}$ content: $1 \mathrm{~mL}$ of the supernatant was taken, and $0.9 \mathrm{~mL}(\mathrm{pH} 7.8)$ of $\mathrm{PBS}, 0.1 \mathrm{~mL} 10 \mathrm{mmol} / \mathrm{L}$ of hydroxylamine hydrochloride (distilled water instead of the sample supernatant was used as a blank) was added. After mixing, it was incubated at $25^{\circ} \mathrm{C}$ for $20 \mathrm{~min}$. Took $0.5 \mathrm{~mL}$ of the above culture solution, added $0.5 \mathrm{~mL}$ $17 \mathrm{mmol} / \mathrm{L} \mathrm{p}$-aminobenzenesulfonic acid, $0.5 \mathrm{~mL} 7 \mathrm{mmol} / \mathrm{L}$ a-naphthylamine, and kept the reaction in a constant temperature water bath at $25^{\circ} \mathrm{C}$ for $20 \mathrm{~min}$, added $1.5 \mathrm{~mL}$ of n-butanol, after homogenization, the n-butanol phase was taken to determine the OD value at $530 \mathrm{~nm}$. Using $\mathrm{NaNO}_{2}$ as the standard, according to the measured OD530, check the $\mathrm{NO}_{2}{ }^{-}$standard curve, convert OD530 into $\left[\mathrm{NO}_{2}^{-}\right]$, and $\left[\mathrm{NO}_{2}^{-}\right] \times 2$ to obtain $\left[\mathrm{O}_{2}{ }^{-}\right]$content.

\section{Analysis of functional components}

Total phenolics: mushroom tissues $(2 \mathrm{~g})$ were homogenized with $80 \mathrm{~mL}$ water, boiled at $100^{\circ} \mathrm{C}$ for 30min, settled to permit after cooling, then filtered. Color was developed by mixing $1 \mathrm{ml}$ filtrate, $5 \mathrm{~mL}$ water, $1 \mathrm{~mL}$ Folin-Ciocalteu (Sigma-Aldrich Chemical Co., St. Louis, Mo, USA) and $3 \mathrm{ml} 7.5 \%$ sodium carbonate solution. After $2 \mathrm{~h}$, the absorbance of solution was measured at $765 \mathrm{~nm}$ wavelength. Total phenolics concentration was calculated according to Singleton \& Rossi (1964) and expressed as gallic acid equivalents, in $\mathrm{mg} / \mathrm{g}$ fresh sample (FW).

Extraction crude extract of SOD and CAT: homogenized frozen tissue $(2 \mathrm{~g})$ with $8 \mathrm{~mL}$ of $50 \mathrm{mM}$ sodium phosphate buffer $(\mathrm{pH} 7.0)$, then centrifuged at $10,000 \mathrm{~g}$ for $10 \mathrm{~min}$ at $4^{\circ} \mathrm{C}$ and took the supernatant. SOD activity was determined according to Jiang et al. (2010). The reaction mixture contained: $1 \mathrm{~mL}$ crude extract $+750 \mu \mathrm{mol} / \mathrm{L}$ nitro-blue tetrazolium (NBT) $+130 \mathrm{mmol} / \mathrm{L}$

methionine $+0.1 \mathrm{mmol} / \mathrm{L}$ EDTA $+20 \mathrm{mmol} / \mathrm{L}$ riboflavin in $0.05 \mathrm{~mol} / \mathrm{L} \mathrm{K}$-phosphate buffer (pH7.8). The reaction was started by adding riboflavin and placing the tubes of reaction mixture under $40001 \mathrm{x}$ irradiance at $25^{\circ} \mathrm{C}$ for $1 \mathrm{~h}$. The absorbance was recorded at $560 \mathrm{~nm}$. The $50 \%$ inhibition of NBT photoreduction was expressed as one SOD activity unit.

CAT activity was assayed according to the method of Candan \&Tarhan (2003). The reaction mixture contained: $1 \mathrm{~mL}$ of $50 \mathrm{mM}$ sodium phosphate buffer $(\mathrm{pH} 7.0)+1 \mathrm{~mL}$ of $0.2 \% \mathrm{H}_{2} \mathrm{O}_{2}+1 \mathrm{~mL}$ of CAT extract. One unit of CAT activity was defined as the amount of enzyme that decomposed $1 \mu \mathrm{mol} \mathrm{H}_{2} \mathrm{O}_{2}$ per min at $30^{\circ} \mathrm{C}$.

POD was extracted and determined according to the methods of Bi et al. (2011).Weighed 2g of shredded and mixed mushrooms, a little quartz sand, $7 \mathrm{~mL}$ of pre-cooled $0.1 \mathrm{~mol} / \mathrm{L} \mathrm{pH} 5.5$ sodium acetate monoacetate buffer (containing $4 \%$ polyvinylpyrrolidone), grinded on ice bath, then centrifuged $\left(10000 \mathrm{r} / \mathrm{min} 4^{\circ} \mathrm{C}\right)$ for $30 \mathrm{~min}$, and took the supernatant. The enzyme reaction system includes: $3 \mathrm{~mL} 25 \mathrm{mmol} / \mathrm{L}$ guaiacol $+0.5 \mathrm{~mL}$ the above supernatant $+200 \mathrm{uL} 0.5 \mathrm{~mol} / \mathrm{L} \mathrm{H}_{2} \mathrm{O}_{2}$

Peer) reviewing PDF | (2019:10:41863:2:0:NEW 26 Dec 2019) 
160

161

162

163

164

165

166

167

168

169

170

171

172

173

174

175

176

177

178

179

180

181

182

183

184

185

186

187

188

189

190

191

192

193

194

195

196

solution, quickly mixed and simultaneously recorded the absorbance at $470 \mathrm{~nm}$ when the reaction was $15 \mathrm{~s}$, as the initial value. Record every 30 s and recorded continuously for 3 minutes. The absorbance value was plotted against time, and the initial straight line portion of the reaction was taken to calculate the change value per minute. One viability unit (U) was defined as the amount of enzyme required to cause a change in absorbance of 0.01 per minute under the assay conditions.

Polyphenol oxidase (PPO) was extracted and determined according to the methods of Li et al. (2006).Weighed $2 \mathrm{~g}$ of shredded and mixed mushrooms, added a little quartz sand and $7 \mathrm{~mL}$ of pre-cooled $0.05 \mathrm{~mol} / \mathrm{L}$ phosphate buffer (PBS, pH5.0), grinded, then centrifuged $\left(4^{\circ} \mathrm{C}, 10000 \mathrm{r} /\right.$ $\mathrm{min}, 15 \mathrm{~min}$ ) and collected the supernatant. The enzyme reaction system includes: $2.5 \mathrm{~mL}$ $0.05 \mathrm{~mol} / \mathrm{L}$ PBS $+0.4 \mathrm{~mL} 0.1 \mathrm{~mol} / \mathrm{L}$ catechol solution (present) $+0.5 \mathrm{~mL}$ PPO crude enzyme solution. PPO active unit (U) was set at 0.001 change per minute at $410 \mathrm{~nm}$ absorbance at $20^{\circ} \mathrm{C}$.

\section{Analysis of cell wall metabolic enzyme activity}

The activity of Chitinase and $\beta$-1,3-glucanase were extracted and determined according to the methods of Ni et al. (2017). Enzyme extraction: $2 \mathrm{~g}$ of each sample was added $7 \mathrm{~mL}$ of $0.1 \mathrm{~mol} / \mathrm{L}$ acetic acid-sodium acetate buffer (pH5.0) and grinded, then centrifuged at $10000 \mathrm{r} / \mathrm{min}$ for $20 \mathrm{~min}$ at $4^{\circ} \mathrm{C}$. The supernatants were kept at $4^{\circ} \mathrm{C}$ as enzyme extractions.

Chitinase: $0.5 \mathrm{~mL}$ of enzyme extract was added to $0.5 \mathrm{~mL}$ of $50 \mathrm{mmol} / \mathrm{L} \mathrm{pH} 5.2$ acetic acid-sodium acetate buffer and $0.5 \mathrm{~mL}$ of $10 \mathrm{~g} / \mathrm{L}$ colloidal chitin suspension. The mixture was incubated in a water bath at $37^{\circ} \mathrm{C}$ for $1 \mathrm{~h}$, then, $0.1 \mathrm{~mL}$ of $30 \mathrm{~g} / \mathrm{L}$ helicase was added and the incubation was continued at $37^{\circ} \mathrm{C}$ for $1 \mathrm{~h}$. After the heat preservation, immediately added $0.2 \mathrm{~mL}$ of $0.6 \mathrm{~mol} / \mathrm{L}$ potassium tetraborate solution, $2 \mathrm{ml}$ of 3,5-dinitrosalicylic acid (DNS) reagent, then boiled for 5 min. After cooling, the volume was adjusted to $25 \mathrm{~mL}$. The absorbance was detected at $520 \mathrm{~nm}$ and the boiled enzyme extraction was used as the control.

$$
\text { Chitinase activity }=\frac{\mathrm{n}-\text { acetyl glucosamine weight } \times \text { total extraction volum } \times 1000}{\text { sample volum } \times \text { reaction time } \times \text { sample weight }}
$$

$\beta$-1,3-glucanase: Two tubes were taken and $1 \mathrm{~mL}$ of $4 \mathrm{~g} / \mathrm{L}$ of laminarin solution was added. Then, $1 \mathrm{~mL}$ of the enzyme solution was added to one tube, and $1 \mathrm{~mL}$ of boiled enzyme solution was added to the other tube as a control. After mixing, the reaction tube was placed in a $37^{\circ} \mathrm{C}$ water bath for $40 \mathrm{~min}$. After the incubation, $1.8 \mathrm{~mL}$ of distilled water and $2 \mathrm{~mL}$ of DNS reagent were added to the reaction tube, and boiled for $5 \mathrm{~min}$, then diluted the reaction solution to $25 \mathrm{~mL}$ with distilled water. The absorbance of the mixture at $540 \mathrm{~nm}$ was measured and repeated 3 times.

$$
\beta-1,3-\text { glucanase activity }=\frac{\text { glucose weight } \times \text { total extraction volum } \times 1000}{\text { sample volum } \times \text { reaction time } \times \text { sample weight }}
$$

\section{Observation of cell structure by transmission electron microscope (TEM)}

According to the methods of Yan (Yan, Wang \& Li, 2002). The tissues of C. comatus with length and width of about $2 \mathrm{~mm} \times 1 \mathrm{~mm}$ was cut out, fixed in $3.5 \%$ pentanediol, washed with $0.1 \mathrm{~mol} / \mathrm{L}$ phosphate buffer of $\mathrm{pH} 7.2$, fixed with $1 \%$ azelaic acid, and flushed with $0.1 \mathrm{~mol} / \mathrm{L}$ phosphate buffer. Then, 35\%, 45\%, 60\%, 70\%, 80\%, 95\%, 100\% ethanol gradient dehydration, propylene 
197

198

199

200

201

202

203

204

205

206

207

208

209

210

211

212

213

214

215

216

217

218

219

220

221

222

223

224

225

226

227

228

229

230

231

232

233

234

235

236

oxide transition and Spurr resin impregnation embedded. After polymerizing at $20^{\circ} \mathrm{C}$ for $8 \mathrm{~h}$, sliced, double stained with uranyl acetate-lead citrate, and observed by TEM.

\section{Statistical analysis}

Data were subjected to analysis of variance (One-Way ANOVA) and least significant differences (LSD) at the 5\% level $(\mathrm{P} \leq 0.05)$ were used for comparing means using the software package SPSS v24 (SPSS Inc., Chicago, USA). Graphs were created using Origin 2018 (Origin 2018., San Diego, USA).

\section{Results}

\section{Appearance and browning evaluation}

The appearance quality of $C$. comatus during the postharvest storage was shown in Fig.1. $C$. comatus exhibited some degree of browning, cap opening and wilting of the whole fruit body after 5 days of storage, and this situation was becoming more and more serious as the storage days went by, since store mushrooms at day 20 were the worst. After 10 days of storage, mushrooms appeared acutely browning, cap opening, stipe extending and flowing black juice, rendering the mushrooms commercially unacceptable.

The fruit body of C. comatus suffered from serious browning during postharvest storage either the stipe or the cap. The color difference value of cap sharply increased from 3.15 at day 0 to 27.67 at day 10 and to 57.91 at day 20 , and the color difference value of stipe followed a similar trend (Fig.2). The color difference value of the cap is basically larger than that of the stipe during storage, indicated that the cap of $C$. comatus were more susceptible to browning than stipe. Between day 5 to day 15 of postharvest storage, the $\Delta \mathrm{E}$ of mushrooms cap increased significantly $(p<0.05)$ by $76.98 \%$, while mushrooms stipe increased significantly $(p<0.05)$ by $91.79 \%$ between day 0 to day 5 .

\section{Weight loss analysis and Membrane permeability}

The ratio of weight loss with respect to storage time and treatments in C. comatus was calculated and the results showed on Figure 3. From the Fig. 3, it is overt that on the whole there was a remarkable increase in the weight loss throughout storage, especially after 10 days weight losses were particularly excessive, thus rendering the $C$. comatus commercially unacceptable. Similar tendency in L. edodes was also reported by Jiang et al. (2010). The weight of $C$. comatus decreased speedy, this may be due to only a thin epidermal structure on the surface of the mushroom, which does not prevent a quick superficial dehydration. Roy (Roy, Anantheswaran \& Beelman, 2006) suggested that water transpiration and $\mathrm{CO}_{2}$ loss during respiration are the main causes of mushroom weight loss. While in our studies, respiration and evaporation might be the main reasons of physiological weight loss rather than transpiration because the relative humidity inside the storage chambers was near saturation.

Whether a membrane system is integrated could be reflected by membrane permeability, and the adversity stress of postharvest plants cell, which could be expressed as electrolyte leakage rate (Ran et al., 2010). From Fig. 3, we can visually see that the electrolyte leakage rates of $C$. comatus rapidly increased during the whole storage (Fig. 3), reaching levels about $149.48 \%$ 
237 higher than the initial values in the end. The results indicated that C. comatus' membrane

238 systems became more vulnerable to leakage during postharvest storage.

239 Analysis of chemical properties

240 Soluble protein, as a nutrient source to support sustaining metabolic activity after picking. In our 241 study, C. comatus contain approximately $3.78 \mathrm{mg} / \mathrm{g} \mathrm{FW}$ soluble protein. A sharp decrease in 242 soluble protein content was observed, and only $60.05 \%$ of the initial levels was retained on the 243 twentieth day (Fig.4). Similar soluble protein level in Agaricus bisporus was also reported by 244 Meng et al. (2012). It is considered as an important indicator of tissue senescence that decline in 245 soluble protein concentration (Burton et al., 1997). This decline may due to the loss of energy 246 sources after picking.

247 MDA is one of the main outcomes of membrane lipid peroxidation, and its content is currently 248 used as the indicator of membrane lipid peroxidation. It can also make large molecules such as proteins and nucleic acids become useless by altering their configuration or cross-linking (Duan et al., 2011). Therefore, the accumulation of MDA can damage the cytoplasm and cell membrane of mushrooms. The MDA content exhibited a gradual upward trend over the whole storage

252

253

254

255

256

257

258

259

260

261

262

263

264

265

266

267

268

269

270

271

272

273

274

275

276 (Fig.5), especially increased significantly $(\mathrm{p}<0.01)$ by $95.82 \%$ between 10 and 15 days after harvest. It seemed that severely damage had happened on cell membrane after day 10 and severe membrane lipid peroxidation occurred in day 15 during the storage. MDA content had an obvious decreasing in 5-10d. This may be related to the increase of antioxidant enzymes activity

Reactive oxygen species (ROS) refer to several metabolites of oxygen with high chemical reactivity, such as $\mathrm{O}_{2}{ }^{--}$and $\mathrm{H}_{2} \mathrm{O}_{2}$. They are considered as toxic by-products in plant metabolism, which can cause damage to macromolecular substances such as lipids (Desikan et al., 2004). The $\mathrm{O}_{2}{ }^{--}$production rate sharply augmented throughout the postharvest period from $8.13 \mathrm{umol} / \mathrm{L}$ to $28.19 \mathrm{umol} / \mathrm{L}$ (Fig. 5), which increased significantly $(\mathrm{p}<0.01)$ by $246.74 \%$. The growth of $\mathrm{O}_{2}{ }^{-{ }^{-}}$ production rate was obvious in the first five days, slowed down in the after 15 days during storage.

\section{Analysis of functional components}

SOD, CAT and POD are the main antioxidant enzymes in edible fungi. During the mushroom postharvest ripening process, they played a vital role in antioxidant defense and were thought to extend food shelf life by protecting the integrity of membranes (Gill \& Tuteja, 2010; Xing et al., 2007). Time courses of SOD activity is shown in Fig. 6. SOD activity increased slowly at the beginning of postharvest storage, afterward increased rapidly. peaked at the day $10\left(31.62 \mathrm{U} \cdot \mathrm{g}^{-}\right.$ ${ }^{1} \cdot \mathrm{Fw}$ ), and then exhibited a sharply downward trend. A CAT activity increase was watched during the first 15 days of storage, and then exhibited a slight drop over the next 5 days (Fig.6). A relatively large increase of CAT activity was recorded between day 5 to day 15, with an increase of 30 folds. POD could help plants get rid of reactive oxygen species (ROS) and was one of the membrane lipid peroxidation defense systems of fruit and vegetable (Terefe, Buckow \& Versteeg, 2014). The changes of POD activity during the postharvest storage are also displayed in Fig. 6. A rapid increase was observed during the first 5 days, then slowly up to a higher peak $(0.33 \mathrm{U} / \mathrm{g} \mathrm{FW})$ at day 10 , afterwards sharply dropped to raw value. 
277

278

279

280

281

282

283

284

285

286

287

288

289

290

291

292

293

294

295

296

297

298

299

300

301

302

303

304

305

306

307

308

309

310

311

312

313

314

315

A sharply increase was observed in 10 days after harvest, with a higher peak of total phenolics $\left(0.89 \mathrm{mg} \cdot \mathrm{g}^{-1} \cdot \mathrm{FW}\right)$. Then total phenolics level showed a gradual downward trend over the next 10 days (Fig.7). The oxidation of phenolic substances was the main factor of browning in mushroom tissue, which is one of the key factors that influence the shelf-life and product quality of the postharvest mushrooms. In our case, the content of total phenols increased significantly $(p<0.01)$ by $13.39 \%$ between 5 and 10 days after harvest, it may be caused by the reduction of PPO activity, and the occurrence and timing of peak roughly coincides with the cap browning of C. comatus.

The change of PPO activity of $C$. comatus during postharvest storage is given in Fig. 7. It increased rapidly from the initial value, then decreased, afterwards increased to a peak, and finally decrease, nonetheless on the whole there was an uplifted tendency. Similar tendency in Agrocybe aegirit was also reported by Lo \& Pck (2005). PPO participation in enzymatic browning was thought to be the major factor of discoloration of many food (Vámos, Lilly \& Haard, 1981). It catalyzed the oxidation of polyphenols into quinones, which turned into melanin by polymerization, thus severely affecting the mushrooms' nutritional value, flavor and appearance quality. Hence, in order to preventing the synthesis of melanin in the browning of mushrooms, control of PPO activity is indispensable. Increased PPO activity was associated with mushroom browning, suggesting that the browning of C. comatus after postharvest was possibly attributed to the action of PPO.

\section{Cell wall metabolism-related enzyme activity}

The change of cell wall metabolizing enzyme activity of $C$. comatus are given in Figure 8. Studies have shown that the content of chitin in edible fungi decreases due to the effect of chitinase in the storage process. Chitinase hydrolyzes the beta-1, 4-glycoside bond in chitinol to produce n-acetylglucosamine oligomer or monomer (Buitimea et al., 2013). Lim \& Choi (2009) found that the Agaricus bisporus could produce black juice in the process of autolysis at $25^{\circ} \mathrm{C}$ for $15 \mathrm{~h}$. By PCR confirmed that the amount of chitinase synthesis in the process of autolysis of A. bisporus mushroom was significantly higher than that in the normal A. bisporus mushroom. In this study, the activity of Chitinase increased rapidly from the initial low value to a peak during the first 10 days, and finally declined over the next 10 days. $\beta$-Glucanase is a cell-wall-degrading enzyme mainly effective on glucans. $\beta$-1,3-glucanase activity of $C$. comatus increased up to day 10 of storage and decreased thereafter. Thus, the higher degrees of cell wall polysaccharide degradation observed during storage might be due to their high activities.

\section{Changes in stipe ultrastructure}

At 5,000 times magnification, we observed the cell of fresh $C$. comatus maintained complete structure as shown in Fig.9-A. Cells arranged in neat rows and the cell wall structure was complete. There are many nucleus and mitochondria in the cytoplasm. Cell of $C$. comatus stored for 10d was shown in Fig. 9-B, the cells no longer line up. The distance between cells increased and the thickness of the cell wall decreased, at the same time, the number of nucleus and mitochondria decreased. Ultrastructure of C. comatus stored for $20 \mathrm{~d}$ was given in Fig. 9-C, 
316

317

318

319

320

321

322

323

324

325

326

327

328

329

330

331

332

333

334

335

336

337

338

339

340

341

342

343

344

345

346

347

348

349

350

351

352

353

354

355

which showed that cells had lost integrity already. Cell wall cracked and cell contents permeated outside. Hence, C. comatus value had been lost.

At 10,000 times magnification, an integrated cell was observed in Fig. 9-D, the nucleus and organelles were clearly visible. A relatively integrated cell was observed in Fig. 9-E, the nucleus and the organelles become blurred. A dissolved cell was observed as shown in Fig. 9-F, the nucleus and organelles were completely degraded into a dark mass.

At 15,000 times magnification, the structure of mitochondria was clear, and mitochondrial cristae could be observed in fresh $C$. comatus (Fig. 9.G). Cell of C. comatus stored for 10d was shown in Fig. 9.H, mitochondria still existed and mitochondrial membrane was visible. While, the mitochondria had almost degraded when stored for $20 \mathrm{~d}$ (Fig. 9.I), which just reserved the structure of mitochondrial was disabled.

\section{Discussion}

In this study, we created a C. comatus softening model to evaluate changes of sensory characteristics, chemical constituents, antioxidant activities and secondary metabolism of the cell wall during a 20-day storage. C. comatus exhibited some degree of browning, wilting of the whole fruit body and cap opening after 5 days of storage, and this situation was becoming more and more serious as the storage days went by. The cap of $C$. comatus were more susceptible to browning than stipe. Due to removing waters and nutrients after harvest, weight loss and soluble protein declined. The continuous production of MDA and $\mathrm{O}_{2}{ }^{--}$leads to the increasing permeability of cell membrane, further leads to membrane lipid peroxidation. While, the increased activity of SOD, CAT and POD can beneficial in protecting cells from ROS-induced injuries, alleviating lipid peroxidation and stabilizing membrane integrity.

Color and textural changes are the two main factors limiting mushroom quality and shelf life (Soler et al., 2010). In our study, relatively high positive correlation ( $\mathrm{r} \geq 0.789)$ was found between browning and polyphenol oxidase (PPO) enzyme. Thus, the browning of $C$. comatus after postharvest was possibly attributed to the action of PPO. May be by inhibiting the activity of PPO, the color quality of $C$. comatus can be effectively improved. Firmness decrease during storage is generally attributed to changes in cell wall composition (Manolopoulou et al., 2007; Singh et al., 2010). Ripening-related modifications in cell wall composition and structure are commonly attributed to the finely tuned, coordinated action of a number of specific enzymatic and non-enzymatic proteins on different cell wall polysaccharides, which eventually lead to cell wall disassembly (Belge et al., 2015). Ni et al. (2017) studied secondary metabolism associated with softening of Lentinula edodes at room temperature, and found that glucanase activity reached the highest level at day 3, chitinase activity and cellulase activity increased since day 3 still day 6 during storage. Karakurt \& Toka (2016) studied the effects of $\mathrm{CaCl}_{2}$ and hot water dips on the change hydrolase activities of Agaricus bisporus, and found xyloglucanase and beta glucanase activities increased significantly during storage. In our study, the cell wall metabolizing enzymes, including Chitinase, $\beta$-1,3-glucanase, they all increased firstly and reached the highest level at day 10 during postharvest storage, then decreased. Thus, it is possible that the higher degrees of cell wall degradation observed during storage might be due to 
356

357

358

359

360

361

362

363

364

365

366

367

368

369

370

371

372

373

374

375

376

377

378

379

380

381

382

383

384

385

386

387

388

389

390

391

392

393

394

their high activities. Liu et al. (2015) suggested that $\beta-1,3$-glucanases plays a major role in the autolysis of Coprinopsis cinerea. In our experiment, the activity of $\beta-1,3$-glucanases was the strongest among cell wall metabolizing enzymes. It is also known that $\beta-1,3$-glucan with $\beta-1,6-$ glucan braches are the backbone of the fungal cell wall network (Aimanianda et al., 2017). Based on the above, we speculate $\beta$-glucanases could destroy the cytoskeleton of $C$. comatus, while the chitinases may degrade cell walls in synergy with $\beta$-1,3-glucanases. Surely, the activity of enzymes is ultimately regulated by genes expression, so more experiments are needed to verify this speculation in the next time. The ultrastructure changes of the postharvest $C$. comatus were observed for the first time. The nucleus, mitochondria had disappeared and thinner cell wall were detected with the storage duration. The lower integrity of cell walls may result in greater loss of protein and polysaccharide.

ROS accumulates and leads to lipid peroxidation when plants suffer from biotic and abiotic stresses (Ren et al., 2012). MDA is a lipid peroxidized product, and it can reflect the extent of ROS-induced membrane lipid peroxidation (You et al., 2012). In this experiment, the MDA content exhibited a gradual upward trend over the whole storage, especially increased significantly $(\mathrm{p}<0.01)$ by $95.82 \%$ between 10 and 15 days after harvest. The result seems to indicate that severely damage had happened on cell membrane after day 10 and severe membrane lipid peroxidation occurred in day 15 during the storage. To protect cells from ROSinduced injuries, plant tissues generated SOD, CAT and POD to scavenge ROS (Duan et al., 2011). In our experiment, showed high activity and the $\mathrm{O}_{2}{ }^{--}$production rate increased slowly between 5 and 15 days after harvest. It validates that high SOD, CAT, POD activity could be beneficial in protecting cells from ROS-induced injuries, alleviating lipid peroxidation and stabilizing membrane integrity. Although the activity of SOD, CAT, POD of C. comatus peaked up to $31.62 \mathrm{U} \cdot \mathrm{g}^{-1} \cdot \mathrm{Fw}, 16.51 \mathrm{U} \cdot \mathrm{g}^{-1} \cdot \mathrm{Fw}, 0.33 \mathrm{U} \cdot \mathrm{g}^{-1} \mathrm{FW}$, respectively, they were lower than that of Agaricus bisporus (Li et al., 2019) at the similar storage conditions. This indicated that enzymatic antioxidant defense of C. comatus was inferior to that of Agaricus bisporus. It also means $C$. comatus were more likely to spoil after harvest. Ding et al. (2016) studied the effects of postharvest brassinolide (BL) treatment on the metabolism of Agaricus bisporus, and found BL treatment significantly decreased the accumulation of ROS and induces the antioxidant enzyme system. Li et al. (2019) also studied storage quality of Agaricus bisporus and the result showed that $10 \mathrm{mM}$ L-arginine treatment inhibited PPO activities, while inducing SOD and POD activities. Lia et al. (2013) explored low oxygen and high carbon dioxide storage effects on reactive oxygen species metabolism in Pleurotus eryngii. They found the activities of SOD, POD, and CAT in $2 \% \mathrm{O}_{2}+30 \% \mathrm{CO}_{2}$ treated mushrooms were significantly higher than those of the control (ambient air). In a study by Shi et al. (2017), the nanocomposite packaging material could effectively delay the postharvest senescence of Flammulina velutipes. Jiang et al. (2010) reported four macroholes treatment was a useful way of maintaining Lentinula edodes texture during storage at $4^{\circ} \mathrm{C}$. Above all, it is possible to apply these methods to the storage of $C$.

comatus, hence prolonged its shelf life. Furthermore, in the future, the expression of genes which

Peer) reviewing PDF | (2019:10:41863:2:0:NEW 26 Dec 2019) 
395

396

397

398

399

400

401

402

403

404

405

406

407

408

409

410

411

412

413

414

415

416

417

418

419

420

421

422

423

424

425

426

427

428

429

430

431

432

433

434

435

436

437

associated with antioxidant activity and cell wall metabolism could be artificially regulated through gene editing, so as to extend the life of $C$. comatus and increased its preservation quality.

\section{Conclusions}

To sum up, these results provide insights into the quality deterioration of C. comatus after postharvest. Identifying and reducing the quality deterioration is necessary to provide the edible fungus industry more appropriate recommendations for postharvest management, which would ultimately maximize both sensory and nutritional quality maintenance of fresh mushrooms.

\section{Acknowledgements}

This work was financially supported by the Technology of Sichuan Province (No. 2016NFP0091) and the National Natural Science Foundation (No. 31870309). The funders had no role in study design, data collection andanalysis, decision to publish, or preparation of the manuscript.

\section{References}

Aimanianda V, Simenel C, Garnaud C, Clavaud C, Tada R, Barbin L. 2017. The dual activity responsible for the elongation and branching of $\beta-(1,3)$-glucan in the fungal cell wall. mBio 8(3): e00619-17 DOI 10.1128/mbio.00619-17

Bailey C J, Turner S L, Jakeman K J. Hayes W A. 1985. Effect of Coprinus comatus on plasma glucose concentrations in mice. Planta Medica 50:525-526 DOI 10.1055/s-2007-969791.

Belge B, Comabella E, Graell J, Lara I. 2015. Post-storage cell wall metabolism in two sweet cherry (Prunus avium L.) cultivars displaying different postharvest performance. Food Science and Technology International 21(6):416-427 DOI 10.1177/1082013214541863.

Bi X, Wu J, Zhang Y, Xu Z, Liao X. 2011. High pressure carbon dioxide treatment for fresh-cut carrot slices. Innovative Food Science \& Emerging Technologies 12(3):0-304 DOI 10.1016/j.ifset.2011.04.001.

Bo L, Fei L, Xiaomin S, Haijuan N, Bin L. 2010. Antioxidant Properties of Cap and Stipe from Coprinus comatus. Molecules 15(3):1473-1486 DOI 10.3390/molecules15031473.

Bradford MM. 1976. A Rapid and Sensitive Method for the Quantitation of Microgram Quantities of Protein Utilizing the Principle of Protein-Dye Binding. Analytical Biochemistry 72(1-2):248-254 DOI 10.1016/00032697(76)90527-3.

Buitimea C G V, Rosas B E C, Cinco M F J, Burgos H A, Plascencia J, Cortez R M O, Gálvez R J C. 2013. In Vitro Effect of Antifungal Fractions from the Plants Baccharis glutinosa and Jacquinia macrocarpa on Chitin and $\beta-1,3$-Glucan Hydrolysis of Maize Phytopathogenic Fungi and on the Fungal $\beta-1,3-$ Glucanase and Chitinase Activities. J Food Safe 33(4):526-535 DOI 10.1111/jfs.12085.

Burton K S, Partis M D, Wood D A, Thurston C F. 1997. Accumulation of serine proteinase in senescent sporophores of the cultivated mushroom (Agaricus bisporus). Mycological Research 101(2):146-152 DOI $10.1017 / \mathrm{s} 0953756296002316$.

Candan N, Tarhan L. 2003. Relationship among chlorophyll-carotenoid content, antioxidant enzyme activities and lipid peroxidation levels by $\mathrm{Mg}^{2+}$ deficiency in the Mentha pulegium leaves. Plant Physiology and Biochemistry (Paris) 41:35-40 DOI 10.1016/s0981-9428(02)00006-2.

Desikan R, Cheung M K, Clarke A, Golding S, Sagi M, Fluhr R, Rock C, Hancock J, Neill S. 2004. Hydrogen peroxide is a common signal for darkness- and ABA-induced stomatal closure in Pisum sativum. 
438

439

440

441

442

443

444

445

446

447

448

449

450

451

452

453

454

455

456

457

458

459

460

461

462

463

464

465

466

467

468

469

470

471

472

473

474

475

476

477

478

479

480

481

482

483

Functional Plant Biology 31(9):913-920 DOI 10.1071/FP04035.

Ding Y, Zhu Z, Zhao J, Nie Y, Zhang Y, Sheng J, Meng D, Mao H, Tang X. 2016. Effects of Postharvest Brassinolide Treatment on the Metabolism of White Button Mushroom (Agaricus bisporus) in Relation to Development of Browning During Storage. Food and Bioprocess Technology 9(8):1327-1334 DOI 10.1007/ s11947-016-1722-1.

Duan X, Liu T, Zhang D, Su X, Lin H, Jiang Y. 2011. Effect of pure oxygen atmosphere on antioxidant enzyme and antioxidant activity of harvested litchi fruit during storage. Food Research International 44(7):01911 DOI 10.1016/j.foodres.2010.10.027.

Fan J M, Zhang J S, Tang Q J, Liu Y F, Zhang A Q, Pan Y J. 2006. Structural elucidation of a neutral fucogalactan from the mycelium of Coprinus comatus. Carbohydrate Research 341(9):1130-1134 DOI 10.1016/j.carres.2006.03.039.

Gill S S, Tuteja N. 2010. Reactive oxygen species and antioxidant machinery in abiotic stress tolerance in crop plants. Plant Physiology and Biochemistry 48(12):909-930 DOI 10.1016/j.plaphy.2010.08.016.

Huang R, Xia R, Hu L, Lu Y, Wang M. 2007. Antioxidant activity and oxygen-scavenging system in orange pulp during fruit ripening and maturation. Scientia Horticulturae 113(2):0-172 DOI 10.1016/j.scienta.2007.03. 010.

Jayakumar T, Ramesh E, Geraldine P. 2006. Antioxidant activity of the oyster mushroom, Pleurotus ostreatus, on CCl4-induced liver injury in rats. Food and Chemical Toxicology 44(12): 1989-1996 DOI 10.1016/j.fct.2006.06.025.

Jiang T, Feng L, Li J. 2012. Changes in microbial and postharvest quality of shiitake mushroom (Lentinus edodes) treated with chitosan-glucose complex coating under cold storage. Food Chemistry 131(3):780-786 DOI 10.1016/j.foodchem.2011.08.087.

Jiang T, Jahangir M M, Jiang Z, Lu X, Ying T. 2010. Influence of UV-C treatment on antioxidant capacity, antioxidant enzyme activity and texture of postharvest shiitake (Lentinus edodes) mushrooms during storage. Postharvest Biology \& Technology 56(3):209-215 DOI 10.1016/j.postharvbio.2010.01.011.

Jiang T, Wang Q, Xu S, Jahangir MM, Ying T. 2010. Structure and composition changes in the cell wall in relation to texture of shiitake mushrooms (Lentinula edodes) stored in modified atmosphere packaging. Journal of the Science of Food \& Agriculture 90(5):742-749 DOI 10.1002/jsfa.3876.

Jiang X, Lian M, Han Y, Lv S. 2013. RETRACTED: Antitumor and immunomodul -atory activity of a polysaccharide from fungus Coprinus comatus (Mull.:Fr) Gray. International Journal of Biological Macromolecules 58(26):349-353 DOI 10.1016/j.ijbiomac.2013.04.033.

Karakurt Y, Toka D. 2016. The Influence of Hot Water and Calcium Chloride on the Changes in Cell Wall Composition and the Activities of Cell Wall Hydrolases during Storage in Agaricus bisporus. Journal of Food Biochemistry 40(2):220-226 DOI 10.1111/jfbc.12219.

Li B, Ding Y, Tang X, Wang G, Wu S, Li X. 2019. Effect of 1-arginine on maintaining storage quality of the white button mushroom (agaricus bisporus). Food and Bioprocess Technology DOI 10.1007/s11947-0182232-0.

Li H S. 2006. The Experiment Principle and Technique on Plant Physiology and Biochemistry. Beijing: Higher Education Press.

Lia P, Zhang X, Hua H, Sun Y, Wang Y, Zhao Y. 2013. High carbon dioxide and low oxygen storage effects on reactive oxygen species metabolism in Pleurotus eryngii. Postharvest Biology and Technolog 85(Complete):141-146 DOI 10.1016/j.postharvbio.2013.05.006.

Lim H, Choi H T. 2009. Enhanced expression of chitinase during the autolysis of mushroom in Coprinellus congregatus. Journal of Microbiology 47(2): 225-228 DOI 10.1007/s12275-008-0247-3.

Liu Z, Niu X, Wang J, Zhang W, Yang M, Liu C, Xiong Y, Zhao Y, Pei S, Qin Q, Zhang Y, Yu Y, Yuan

S. 2015. Comparative study of non-autolytic mutant and wild-type strains of Coprinopsis cinerea supports an

Peer) reviewing PDF | (2019:10:41863:2:0:NEW 26 Dec 2019) 
484

485

486

487

488

489

490

491

492

493

494

495

496

497

498

499

500

501

502

503

504

505

506

507

508

509

510

511

512

513

514

515

516

517

518

519

520

521

522

523

524

525

526

527

528

529

important role of glucanases in fruiting body autolysis. Journal of Agricultural \& Food Chemistry 63:96099614 DOI 10.1021/acs.jafc.5b03962.

Liu Z, Wang X, Zhu J, Wang J. 2010. Effect of high oxygen modified atmosphere on post-harvest physiology and sensorial qualities of mushroom. International Journal of Food Science \& Technology 45(6): 1097-1103 DOI 10.1111/j.1365-2621.2010.02199.x.

Lo K M, Cheung P C K. 2005. Antioxidant activity of extracts from the fruiting bodies of Agrocybe aegerita var. alba. Food Chemistry 89(4): 533-539 DOI 10.1016/j.foodchem.2004.03.006.

Manolopoulou E, Philippoussis A, Lambrinos G, Diamantopoulou P. 2007. EVALUATION OF PRODUCTIVITY AND POSTHARVEST QUALITY DURING STORAGE OF FIVE AGARICUS BISPORUS STRAINS. Journal of Food Quality 30(5):18 DOI 10.1111/j.1745-4557. 2007. 0014 8.x.

Meng D, Song T, Shen L, Zhang X, Sheng J. 2012. Postharvest Applicationof Methyl Jasmonate for Improving Quality Retention of Agaricus bisporus Fruit Bodies. Journal of Agricultural and Food Chemistry 60(23):6056-6062 DOI 10.1021/jf3006454.

Ni Z, Xu S, Bu J, Ying T. 2017. Secondary metabolism associated with softening of shiitake mushroom (Lentinula edodes) induced by $\mathrm{O}_{2}$ depletion and $\mathrm{CO}_{2}$ accumulation. International Journal of Food Science \& Technology 52(10):2303-2310 DOI 10.1111/ijfs.13512.

Prasad S B, Rosangkima G, Kharbangar A. 2009. Structural and biochemical changes in mitochondria after cisplatin treatment of Dalton's lymphoma-bearing mice. Mitochondrion 10(1):38-45 DOI 10.1016/j.mito. 2009. 09.002.

Qi X D, Wei J M, Gao H S, Jia Y R, Zhang H. 2015. Pectin Polysaccharide Degradation in Relation to the Texture Softening in Pear Fruit. Scientia Agricultura Sinica.

Ran Z, Li-ping Y, Jing X, Yun-fei L, Heng-he F. 2010. Effects of edible coatings on quality of Shanghai sand pear (Pyrus pyrifolia) during cold storage. Acta Agriculturae Shanghai 26(4):53-56 DOI 10.1080/ 00949 651003724790 .

Ren Y, Wang Y, Bi Y, Ge Y, Wang Y, Fan C, Li D, Deng H. 2012. Postharvest BTH treatment induced disease resistance and enhanced reactive oxygen species metabolism in muskmelon (Cucumis melo L.) fruit. European Food Research and Technology 234(6) DOI 10.1007/s00217-012-1715-x.

Roy S, Anantheswaran R C, Beelman R B. 2006. Fresh Mushroom Quality as Affected by Modified Atmosphere Packaging. Journal of Food Science 60(2):7 DOI 10.1111/j.1365-2621.1995.tb05667.x.

Rui J, Feng-Lan L. 2006. Research current situation and developing prospect of Coprinus comatus. Food Science \& Technology 27(12):890-889 DOI 10.1016/S1872-2040(06)60045-5.

Shi C, Wu Y, Fang D, Pei F, Hu Q. 2017. Effect of nanocomposite packaging on postharvest senescence of Flammulina velutipes. Food Chemistry S0308814617317417 DOI 10.1016/j.foodchem.2017.10.103.

Singh P, Langowski H C, Wani A A, Saengerlaub S. 2010. Recent advances in extending the shelf life of fresh Agaricus mushrooms: A review. J Sci Food Agric 90(9):1393-1402 DOI 10.1002/jsfa.3971.

Singleton V, Rossi J A. 1964. Colorimetry of Total Phenolics with Phosphomolybdic-Phosphotungstic Acid Reagents. American Journal of Enology and Viticulture 16(3) DOI doi:http://dx.doi.org/.

Soler-Rivas C, Arpin N, Olivier J M, Wichers H J. 2010. WLIP, a lipodepsipeptide of Pseudomonas 'reactans', as inhibitor of the brown blotch disease of Agaricus bisporus. Journal of Applied Microbiology 86(4):635-641 DOI 10.1046/j.1365-2672.1999.00709.x.

Terefe N S, Buckow R, Versteeg C. 2014. Quality-related enzymes in fruit and vegetable products: effects of novel food processing technologies, part 1: high-pressure processing. Critical Reviews in Food Science and Nutrition 54(1):24-63 DOI 10.1080/10408398.2011.566946.

Tsai S Y, Tsai H L, Mau J L. 2009. Antioxidant properties of Coprinus comatus. Journal of Food Biochemistry 33:368-389 DOI 10.1111/j.1745-4514.2009.00224. x.

Vámos-Vigyázó, Lilly, Haard N F. 1981. Polyphenol oxidase and peroxidase in fruits and vegetables. Critical

Peer) reviewing PDF | (2019:10:41863:2:0:NEW 26 Dec 2019) 
530 Reviews in Food Science and Nutrition 15(1):49-127 DOI 10.1080/10408398109527312.

531 Xing Z, Wang Y, Feng Z, Zhao Z, Liu X. 2007. Effect of 60 Co irradiation on postharvest quality and 532 selected enzyme activities of Hypsizygus marmoreus fruit bodies. Journal of Agricultural and Food Chemistry 533 55(20):8126-8132 DOI 10.1021/jf070941w.

534 Xue H. 2012. Effect of postharvest calcium treatment on lentinan content and cell stability of Lentinula 535 edodes. Food Science 33(10):298-300.

536 Yan C L, Wang J B, Li R Q. 2002. Effect of heat stress on calcium ultrastructural distribution in pepper 537 anther. Environmental and Experimental Botany 48(2):161-168 DOI 10.1016/s0098-8472(02)00021-7.

538 You Y, Jiang Y, Sun J, Liu H, Song L, Duan X. 2012. Effects of short-term anoxia treatment on browning of 539 fresh-cut Chinese water chestnut in relation to antioxidant activity. Food Chemistry 132(3):1191-1196 DOI 540 10.1016/j.foodchem.2011.11.073.

541 Zivanovic S, Buescher R, Kim S K. 2003. Mushroom Texture, Cell Wall Composition, Color, and 542 Ultrastructure as Affected by $\mathrm{pH}$ and Temperature. Journal of Food Science 68(5):1860-1865 DOI 10.1111/ 543 j.1365-2621.2003. Tb 12343.x. 


\section{Figure 1}

Fig.1. The appearance quality of Coprinus comatus stored at $4{ }^{\circ} \mathrm{C}$ and $90 \% \mathrm{RH}$.

a: stored for $0 \mathrm{~d}$. b: stored for $5 \mathrm{~d}$. c: stored for $10 \mathrm{~d}$. d: stored for $15 \mathrm{~d}$. e: stored for $20 \mathrm{~d}$.
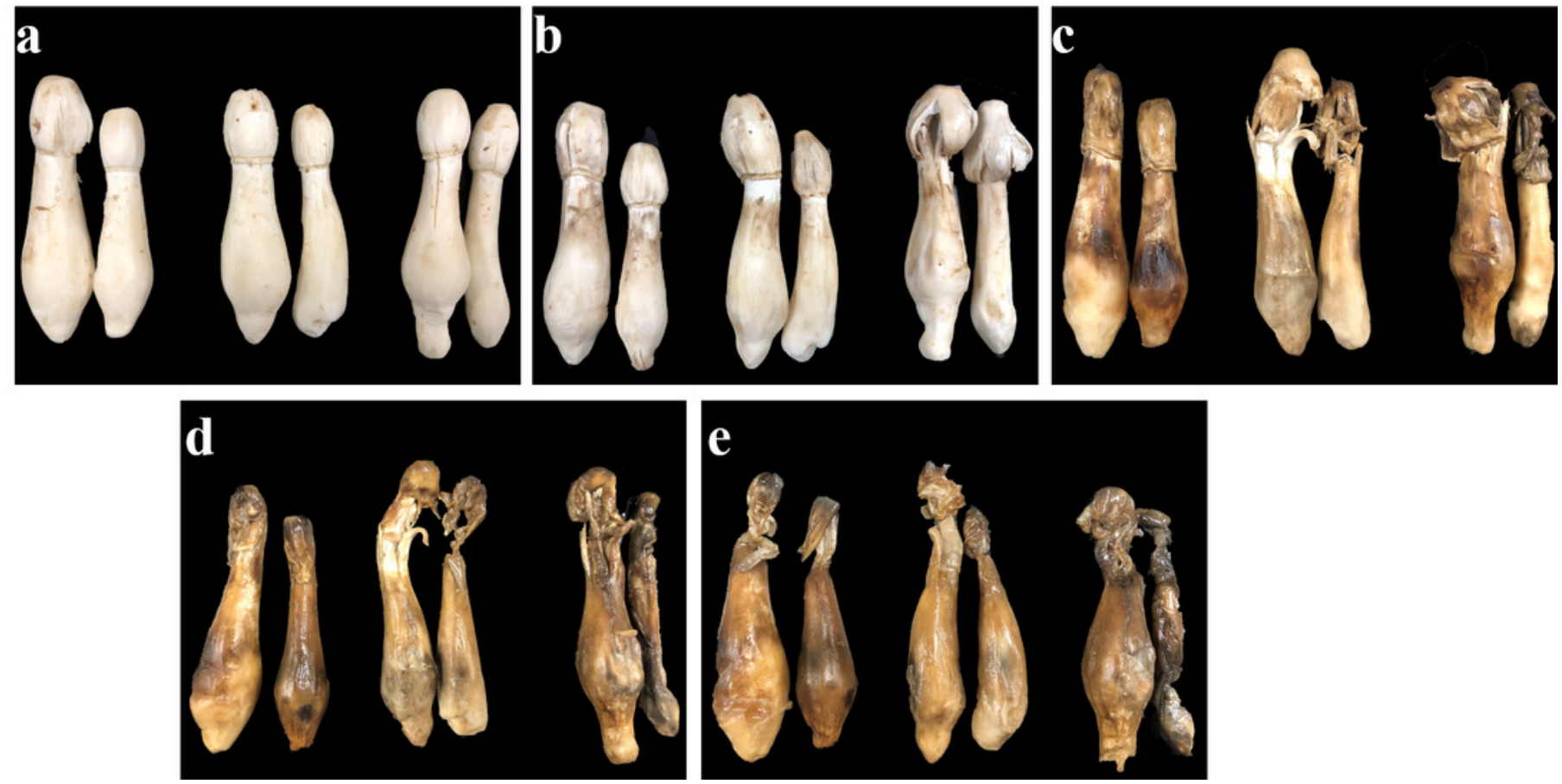
Figure 2

Fig.2. The color difference value of Coprinus comatus stored at $4{ }^{\circ} \mathrm{C}$ and $90 \% \mathrm{RH}$.

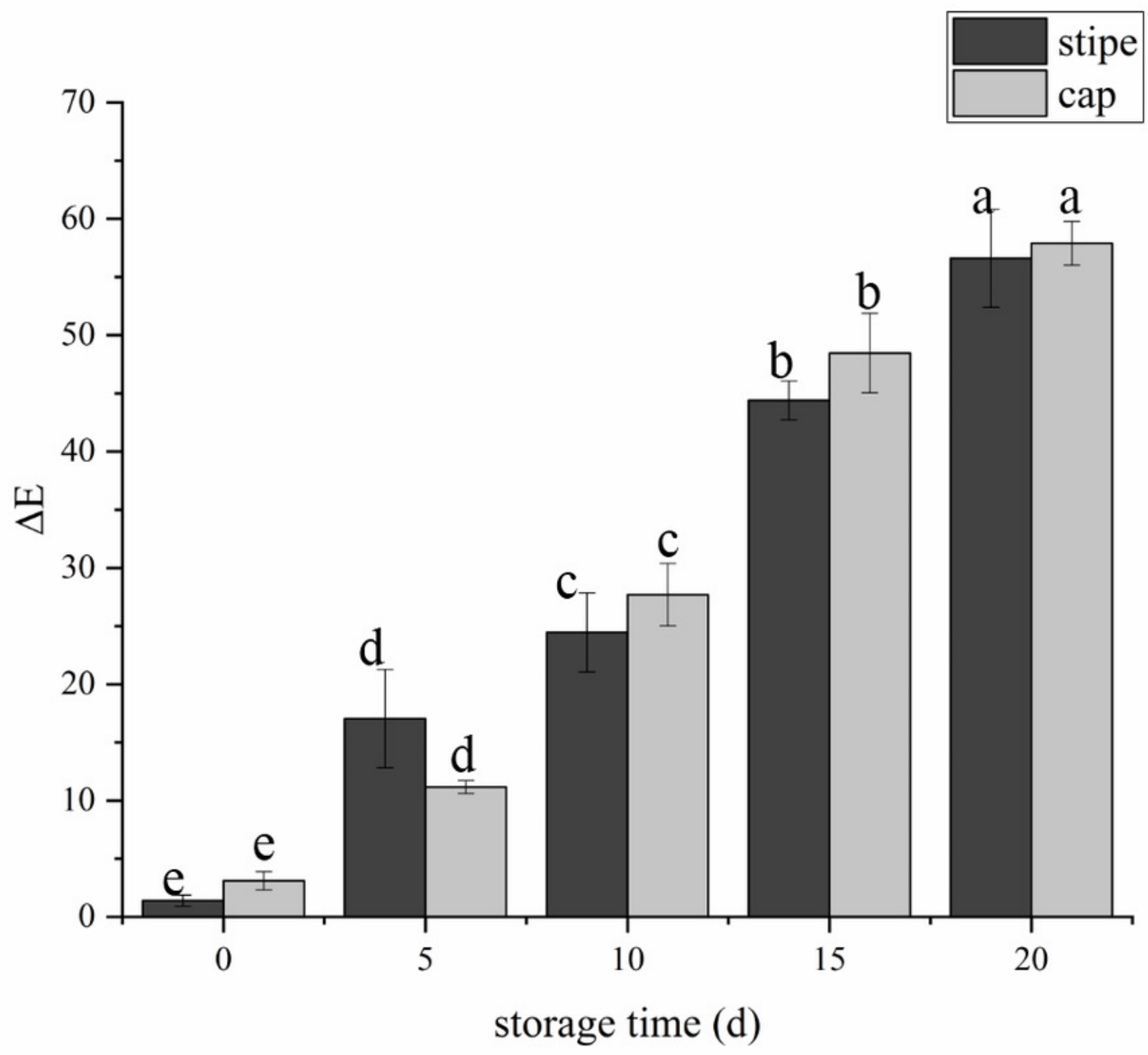


Figure 3

Fig.3. The weight loss ratio and membrane permeability of Coprinus comatus stored at 4 ${ }^{\circ} \mathrm{C}$ and $90 \% \mathrm{RH}$.

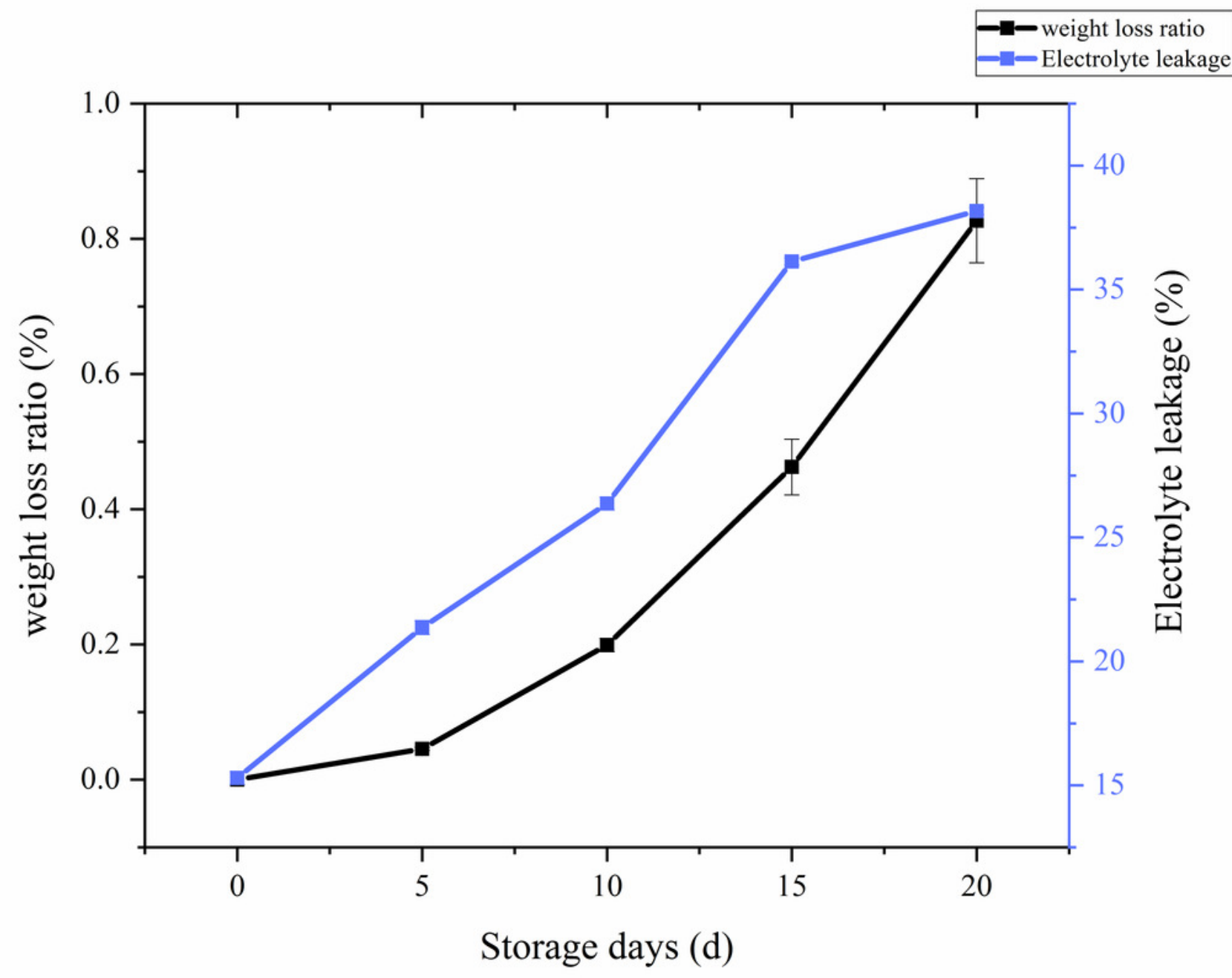


Figure 4

Fig.4. The soluble protein of Coprinus comatus stored at $4{ }^{\circ} \mathrm{C}$ and $90 \% \mathrm{RH}$

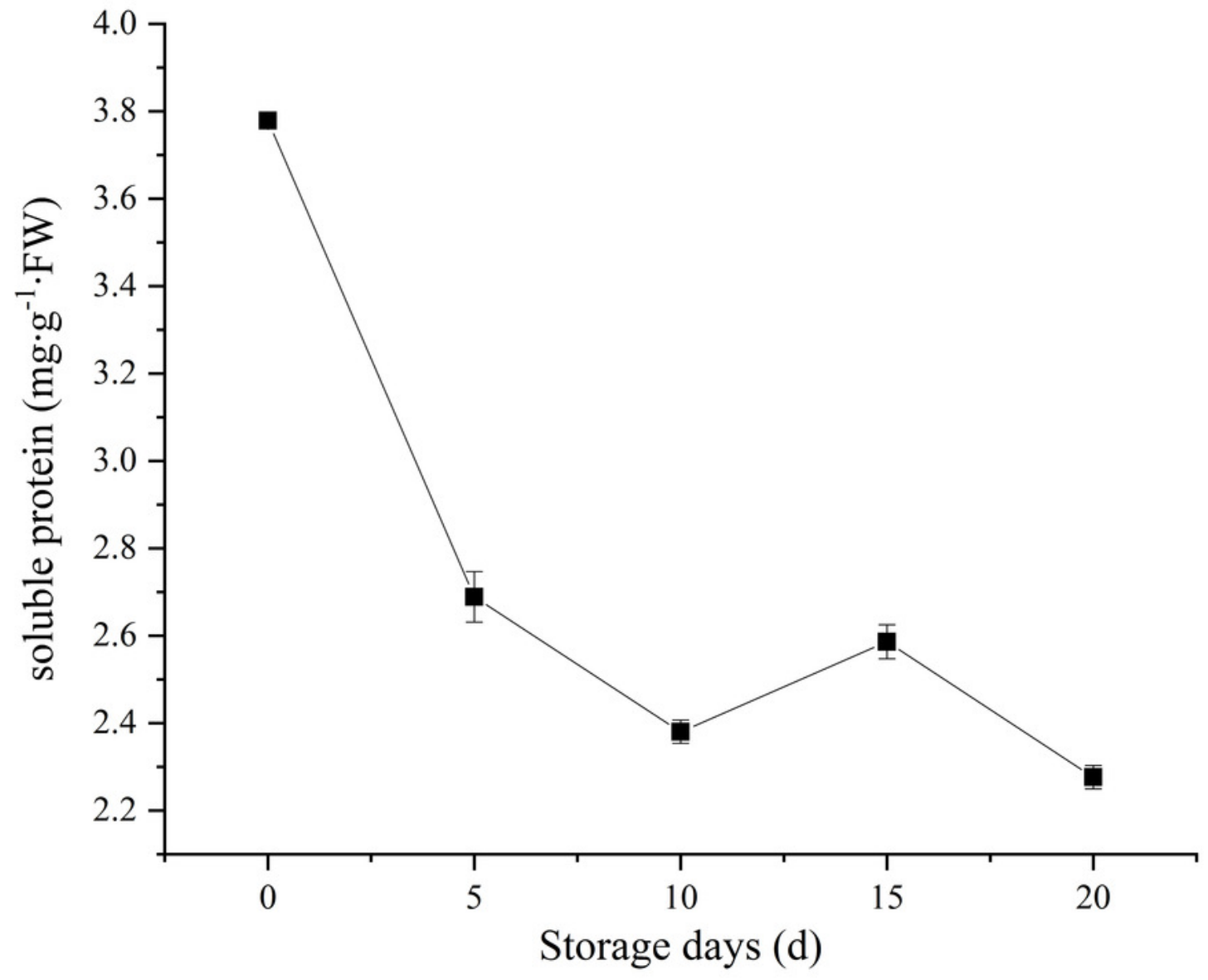


Figure 5

Fig.5. The MDA content and $\mathrm{O}_{2}{ }^{\cdot-}$ production rate of Coprinus comatus stored at $4{ }^{\circ} \mathrm{C}$ and $90 \% \mathrm{RH}$.

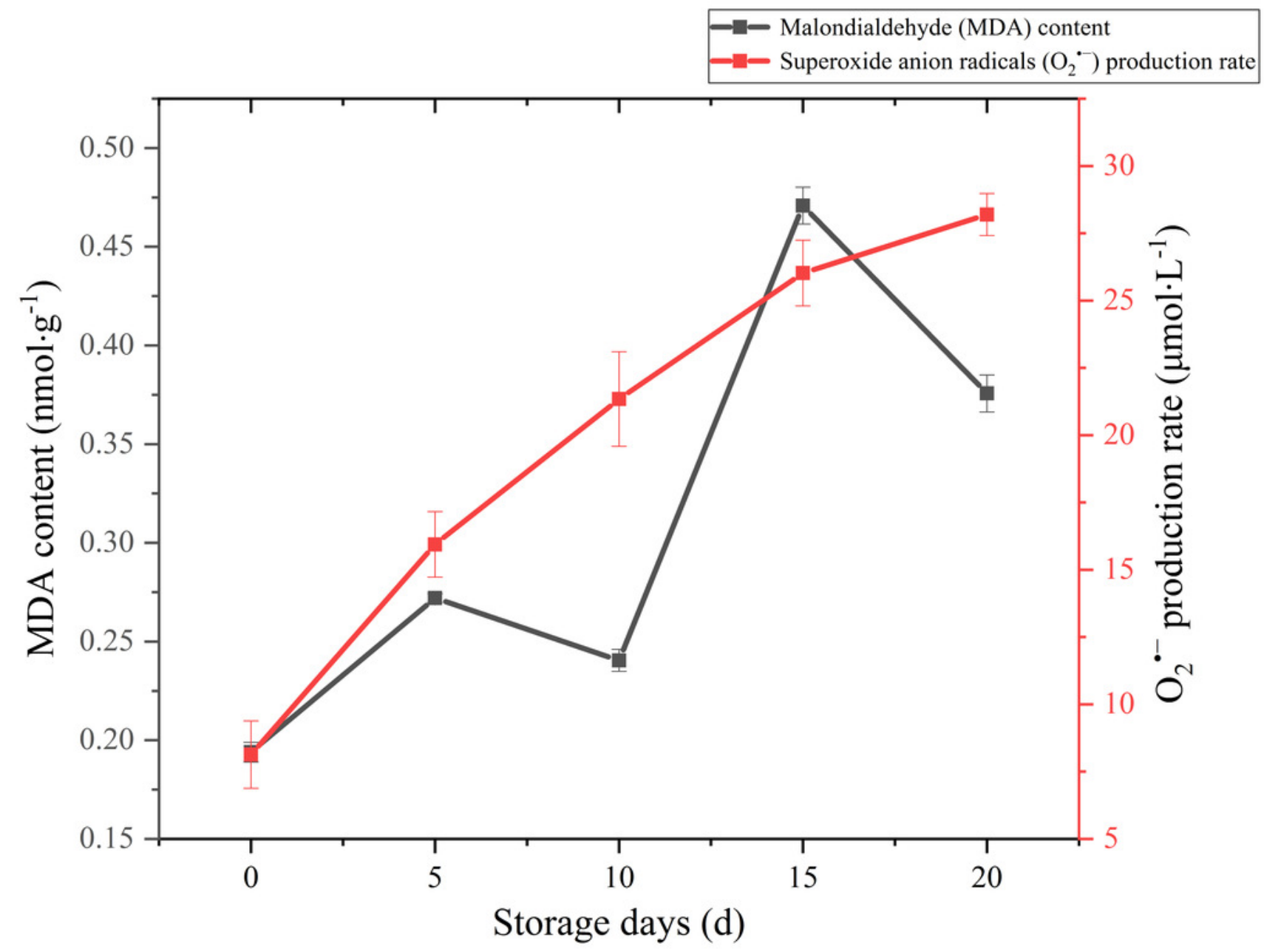


Figure 6

Fig.6. The SOD, CAT, POD activity of Coprinus comatus stored at $4{ }^{\circ} \mathrm{C}$ and $90 \% \mathrm{RH}$.

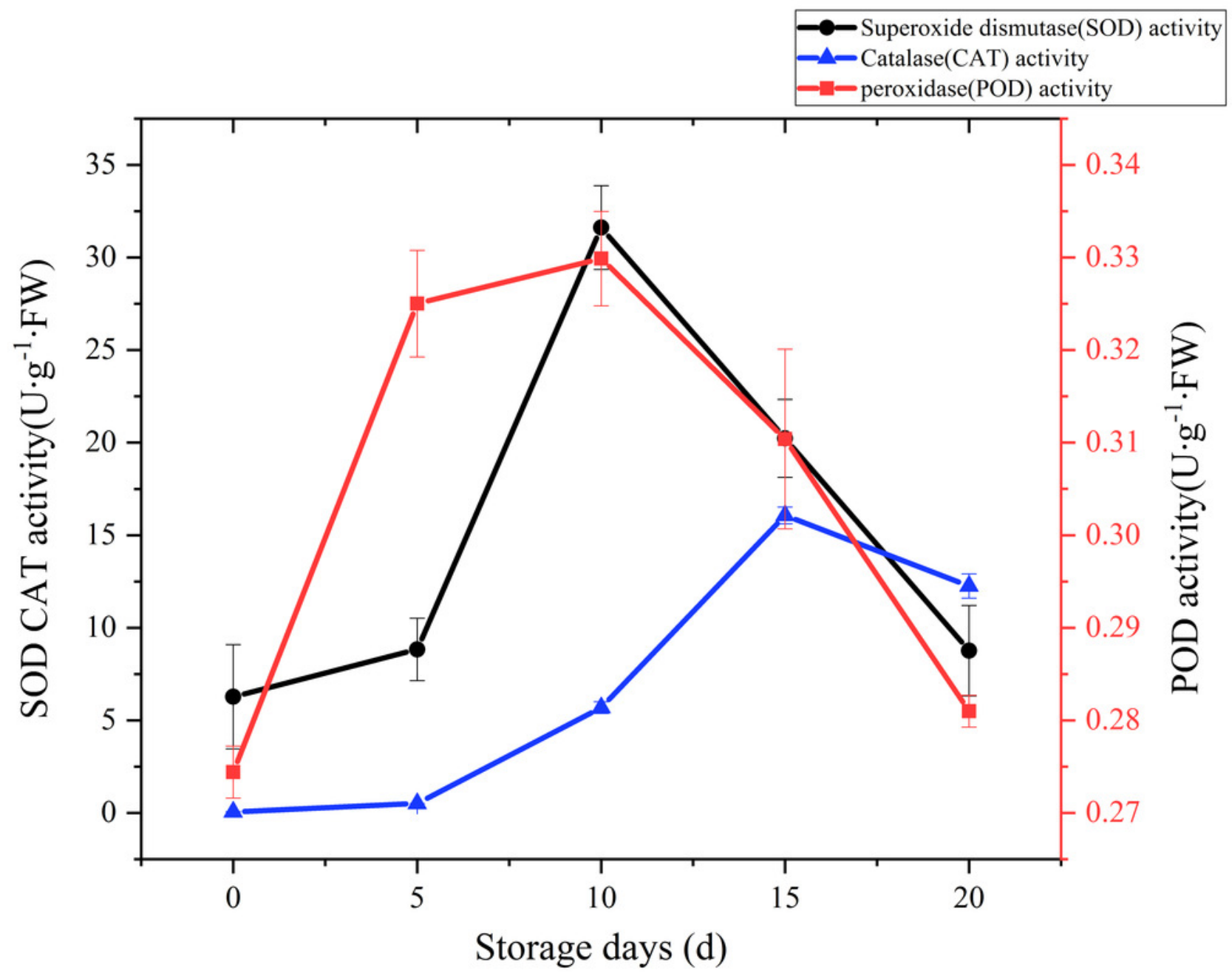


Figure 7

Fig.7. The total phenolics and PPO activity of Coprinus comatus stored at $4{ }^{\circ} \mathrm{C}$ and $90 \%$ $\mathrm{RH}$.

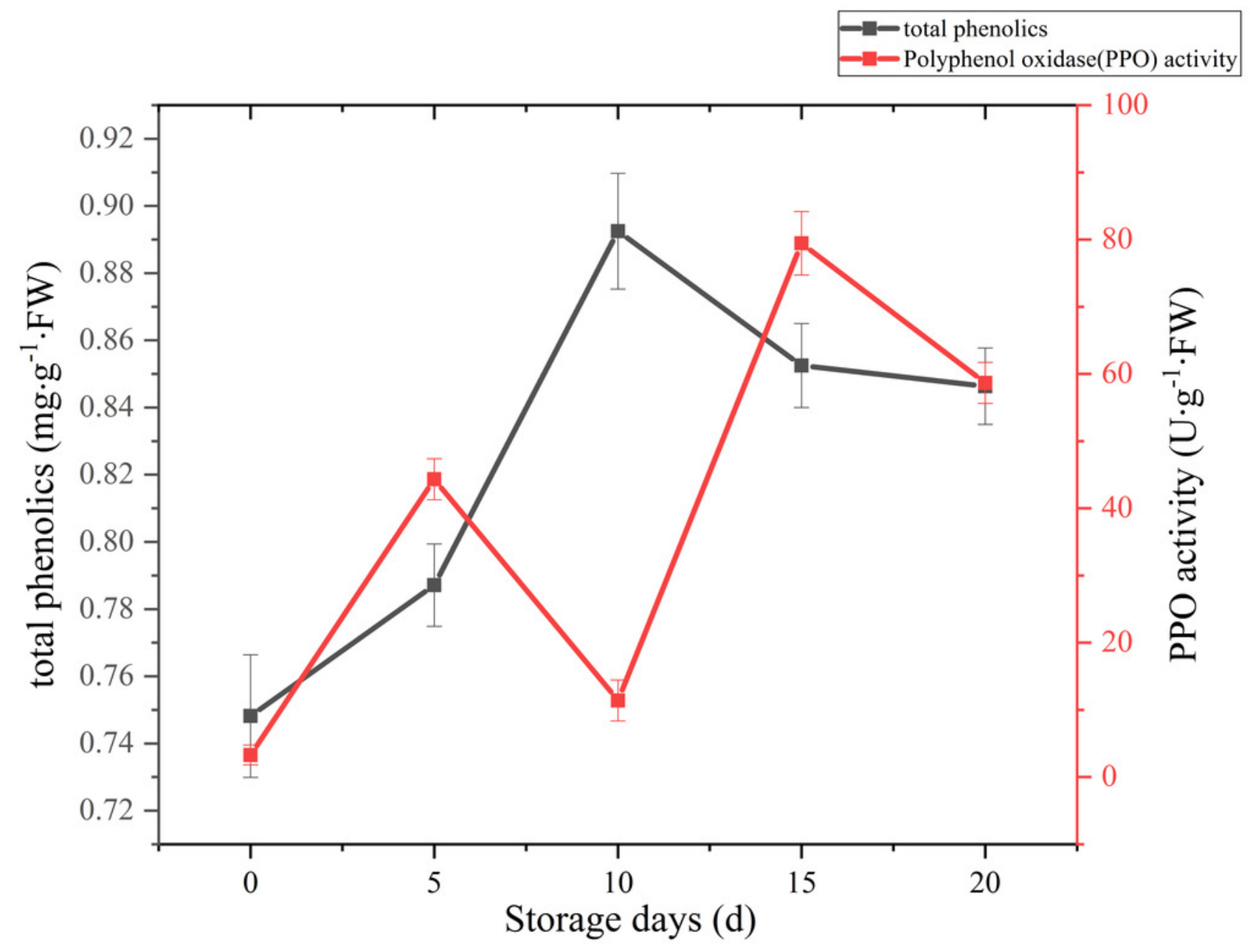


Figure 8

Fig.8. The cell wall metabolizing enzyme activity of Coprinus comatus stored at $4{ }^{\circ} \mathrm{C}$ and $90 \% \mathrm{RH}$.

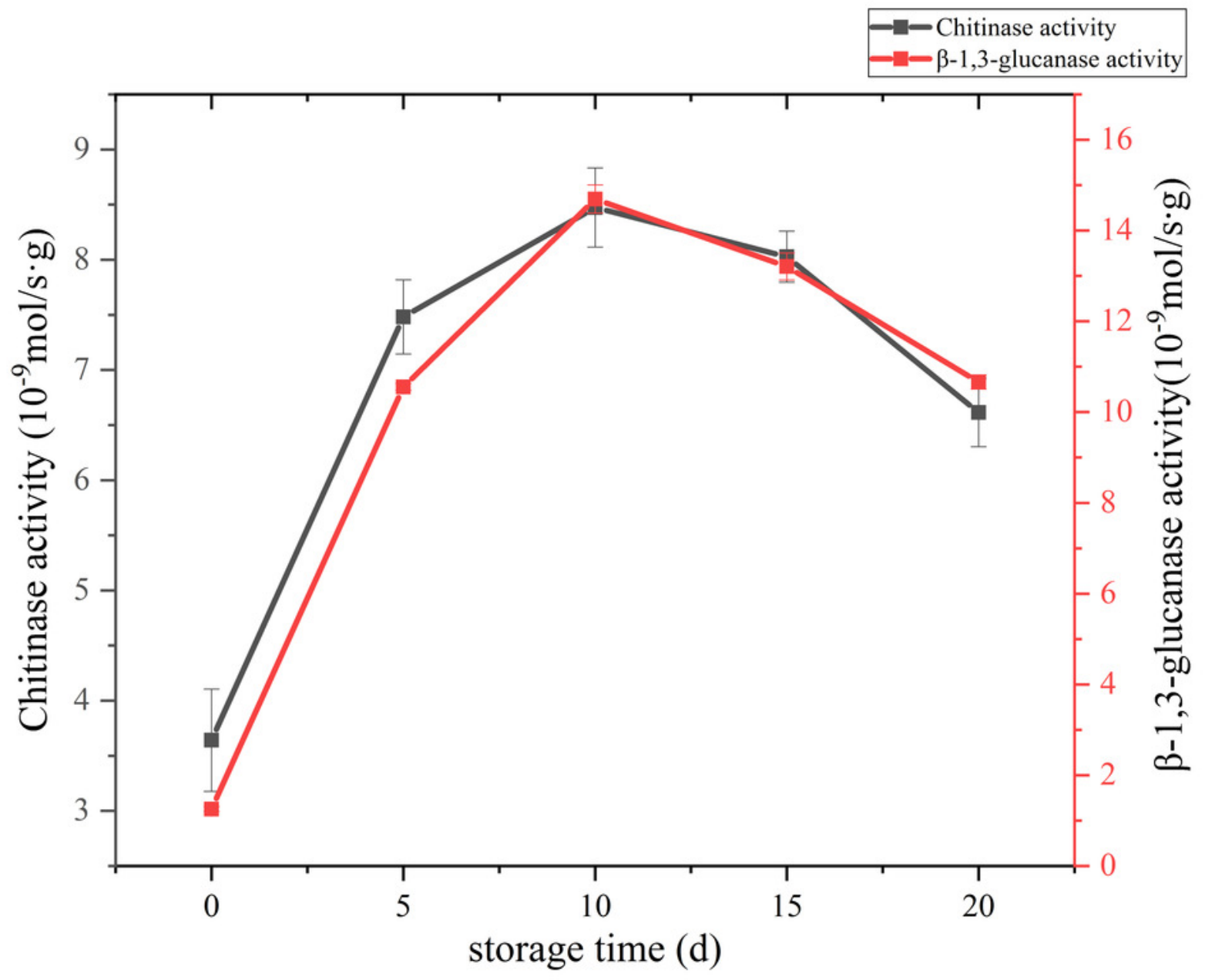




\section{Figure 9}

Fig. 9 Changes in stipe ultrastructure of Coprinus comatu $s$ though TEM stored at $4^{\circ} \mathrm{C}$ and $90 \% \mathrm{RH}$.

A: storage for 0d, B: storage for $10 \mathrm{~d}, \mathbf{C}$ : storage for $20 \mathrm{~d}$. amplification: $5 \times 1000$. D: storage for $0 \mathrm{~d}, \mathbf{E}$ : storage for $10 \mathrm{~d}, \mathbf{F}$ : storage for $20 \mathrm{~d}$. amplification:10×1000. G: storage for $0 \mathrm{~d}, \mathbf{H}$ : storage for $10 \mathrm{~d}$, I: storage for 20d. amplification: $15 \times 1000$.

CW: cell wall, CY: cytoplasm, M: mitochondria, N: nucleus, V: vacuole, IM: mitochondrial inner membrane, OM: mitochondrial outer membrane.
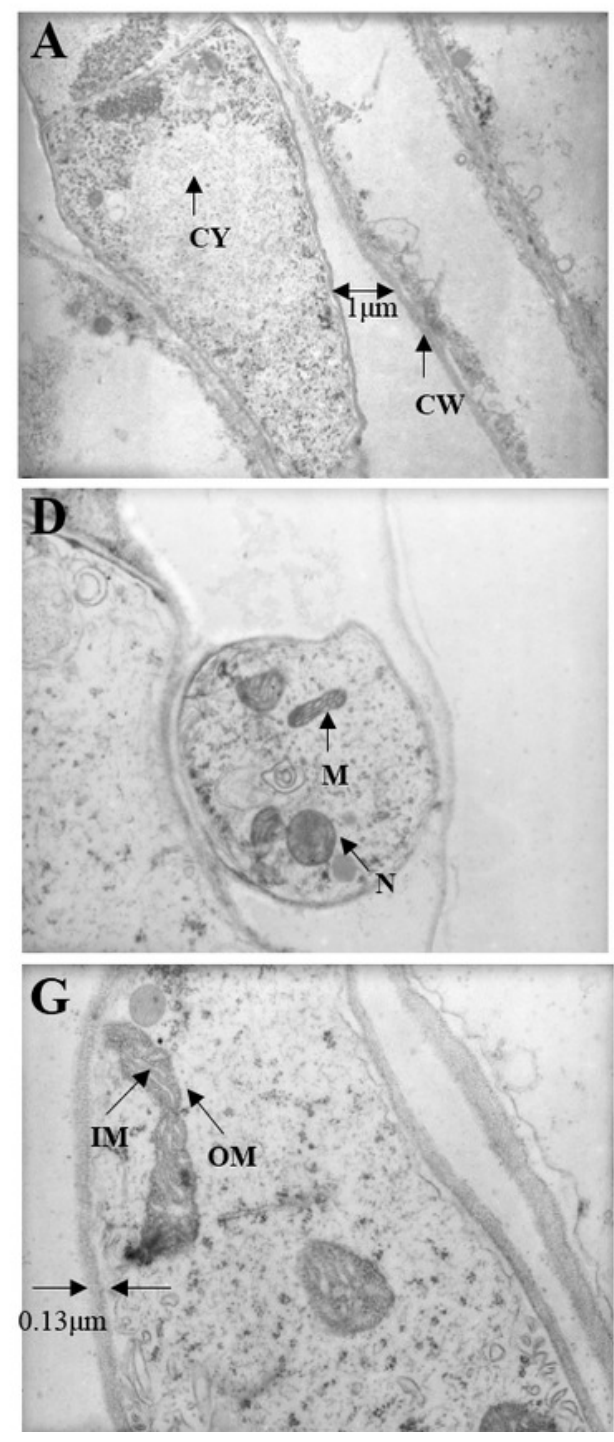
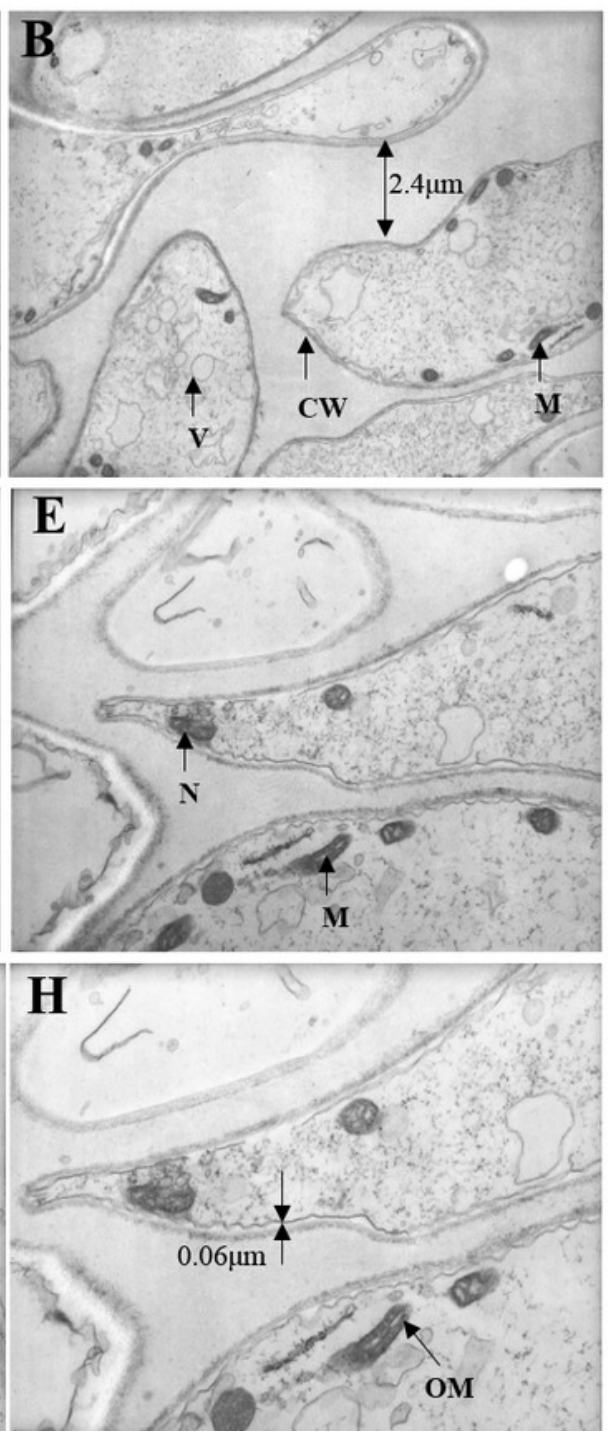
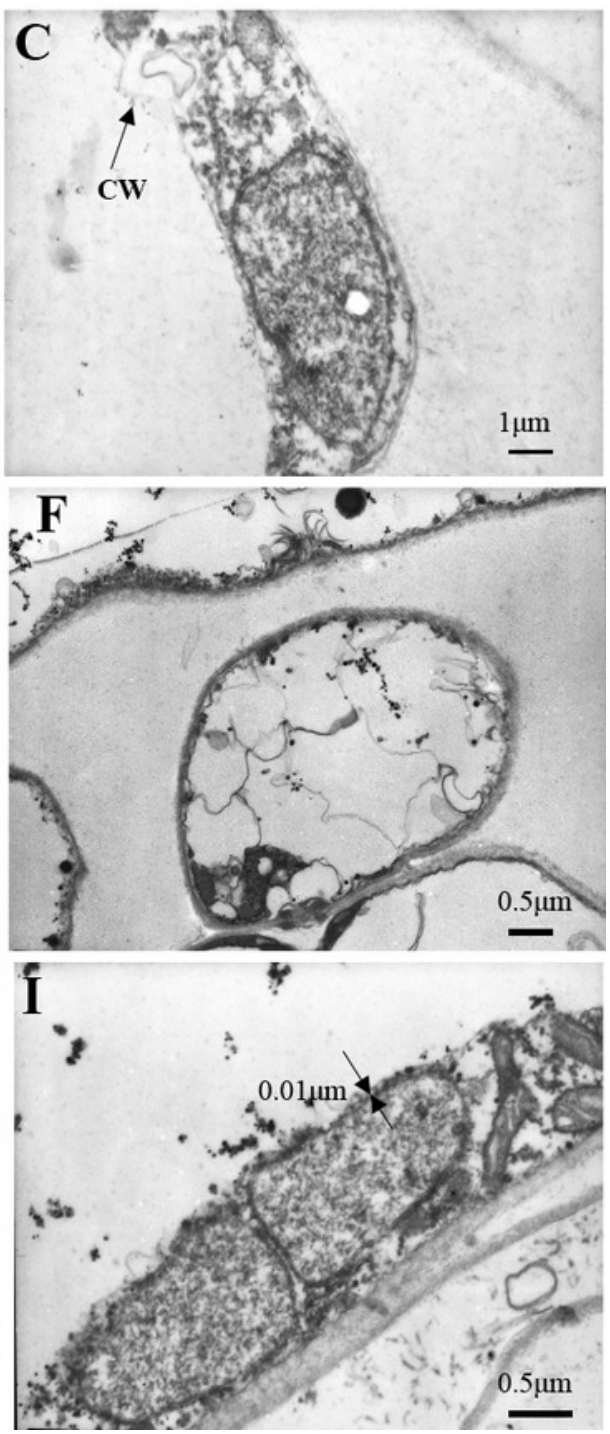